\title{
APLIKASI ELEKTROKOAGULASI DALAM PENGOLAHAN LIMBAH CAIR PABRIK KELAPA SAWIT
}

\author{
Farida Hanum, Rondang Tambun, M. Yusuf Ritonga, William Wardhana Kasim \\ Departemen Teknik Kimia, Fakultas Teknik, Universitas Sumatera Utara \\ Jl. Almamater Kampus USU Medan 20155 Indonesia \\ Email: farida2@usu.ac.id/ida_hanum78@yahoo.co.id
}

\begin{abstract}
Abstrak
Produksi minyak sawit mentah (crude palm oil, CPO) di Indonesia terus meningkat sehingga akan menambah jumlah limbah cair yang dihasilkan. Teknologi reaktor anaerobik unggun tetap (RANUT) telah banyak dikembangkan, namun karakteristik limbah cair effluent RANUT belumlah memenuhi baku mutu limbah cair yang dipersyaratkan oleh pemerintah terutama untuk COD. Oleh karena itu perlu dilakukan penelitian lanjutan tentang pengolahan limbah cair pabrik kelapa sawit dari unit reaktor anaerobik unggun tetap dengan teknik elektrokoagulasi. Elektrokoagulasi merupakan suatu proses koagulasi dengan menggunakan arus listrik searah melalui peristiwa elektrokimia yaitu gejala dekomposisi elektrolit. Penelitian ini bertujuan untuk mengetahui pengaruh parameter tegangan pada adaptor terhadap kinerja sistem elektrokoagulasi serta menentukan waktu terbaik untuk pengolahan limbah cair pabrik kelapa sawit tersebut. Jenis material elektroda yang digunakan adalah aluminium, waktu retensi limbah 1 jam, jarak antar elektroda $5 \mathrm{~cm}$, kuat arus 5 ampere, variasi tegangan adaptor 3, 4, dan 5 volt. Hasil penelitian menunjukkan bahwa hasil terbaik diperoleh pada tegangan 5 volt untuk penyisihan COD sebesar 81,32 \% dengan nilai COD 233,5 mg/l pada waktu pengolahan 180 menit, hal ini menunjukkan bahwa limbah olahan telah memenuhi baku mutu limbah cair PKS untuk COD yaitu $350 \mathrm{mg} / \mathrm{l}$. Adapun persentase penyisihan turbiditas yang tertinggi diperoleh pada tegangan 5 volt dan pada waktu 180 menit dengan perolehan 95,08\%.
\end{abstract}

Kata Kunci : Limbah RANUT, Elektrokoagulasi, Tegangan Adaptor, Elektroda Aluminium, Persentasi Penurunan COD

\begin{abstract}
The production of crude palm oil (CPO) in Indonesia is keep increasing that make the amount of wastewater generated. Technology of anaerobic fixed bed (RANUT) have been developed, but the characteristic of the wastewater effluent of RANUT has not meet the quality standard that required by the goverment especially for COD. Because of that need to make a furhter research about the treatment of palm oil mill from the fixed bed reactor (RANUT) with electrocoagulation technique. Electrocoagulation is a process of coagulation by using a direct current through an electrochemical events are symptoms of electrolyte decomposition. This study aims to determine the effect of voltage on the adapter parameters on the performance of the electrocoagulation system and determine the best time for treatment of palm oil mill effluent. Type of electrode material used is aluminum, waste retention time 1 hour, $5 \mathrm{~cm}$ distance between the electrodes, a strong current of 5 amperes, voltage variations adapter 3,4 , and 5 volts. The results showed that the best results are obtained at a voltage of 5 volts for COD removal $81.32 \%$ with a value $233.5 \mathrm{mg} / \mathrm{l}$ at 180 minutes of processing time, it indicates that the processed waste has met quality standards for mill effluent COD is $350 \mathrm{mg} / \mathrm{l}$. The highest turbidity removal percentage is obtained at a voltage of 5 volts and at a time of 180 minutes with the acquisition of $95.08 \%$.
\end{abstract}

Keywords : RANUT Waste, Electrocoagulation, Adapters Voltage, Alum num Electrodes, Percentage Reduction in COD

\section{PENDAHULUAN}

Indonesia merupakan negara pertama didunia sebagai produsen CPO (Crude Palm Oil), disusul oleh Malaysia dan Thailand [3]. Namun timbul beberapa permasalahan baru, yaitu banyaknya limbah yang dihasilkan. Dimana limbah yang dihasilkan dapat mencemarkan lingkungan apabila tidak diolah dengan baik. Salah satu terjadinya pencemaran adalah banyaknya limbah yang dibuang tanpa diolah terlebih dahulu ataupun sudah diolah, akan tetapi belum memenuhi persyaratan. Hal ini mungkin karena adanya keenganan mengolah air limbah, disamping itu belum tersedianya sebuah teknologi pengolah air limbah yang mudah dan efisien sehingga belum diterapkan oleh industri-industri [5]. Pabrik pengolahan kelapa sawit menghasilkan limbah cair dalam jumlah yang besar, yaitu berkisar antara 600-700 liter/ton tandan buah segar (TBS) atau sekitar 65\% dari TBS. Saat ini diperkirakan jumlah limbah cair pabrik kelapa sawit (LCPKS) di Indonesia mencapai 28,7 juta ton. Jumlah LCPKS yang besar dan kandungan bahan organiknya yang tinggi (80\%) menjadikan peluang besar bagi industri ini dalam pemanfaatan limbah untuk menghasilkan produk lain, salah satunya adalah pemanfaatan LCPKS untuk menghasilkan biogas. Walaupun menghasilkan 
biogas, akan tetapi dari hasil penelitian masih belum memenuhi standar baku mutu [5]. Maka perlu dicari beberapa teknologi pengolahan yang lain yang lebih efisien. Walaupun teknik reaktor anaerobik unggun tetap (RANUT) memberi keuntungan dalam menghasilkan biogas, namun hasil penelitian menunjukkan bahwa karakteristik keluaran (effluent) RANUT belum memenuhi standar baku mutu yang ditetapkan oleh Pemerintah. Oleh sebab itu perlu dilakukan pengolahan lebih lanjut terhadap limbah effluent RANUT.

Adapun alternatif yang dipilih untuk menjawab permasalahan tersebut adalah dengan mengolah limbah effluent RANUT dengan teknik elektrokoagulasi. Elektrokoagulasi merupakan gabungan dari proses elektrokimia dan flokulasikoagulasi. Teknik ini telah dipakai untuk pengolahan limbah cair tekstil [2], mengatasi permasalahan limbah radio aktif, penanganan limbah cair rumah potong hewan, air limbah rumah tangga, dan limbah cair kimiawi dari industri fiber [1].

\section{Teori}

Proses elektrokoagulasi pada prinsipnya berdasarkan pada proses sel elektrolisis. Sel elektrolisis merupakan suatu alat yang dapat mengubah energi listrik DC (direct current) untuk menghasilkan reaksi elektrodik. Setiap sel elektrolisis mempunyai dua elektroda, katoda dan anoda. Jenis elektroda yang digunakan pada penelitian ini adalah elektroda Aluminium yang berperan sebagai sumber ion $\mathrm{Al}^{+3}$ di anoda dan berfungis sebagai koagulan dalam proses koagulasi-flokulasi yang terjadi di dalam sel tersebut. Sedangkan di katoda terjadi reaksi katodik dengan membentuk gelembung-gelembung gas hidrogen yang berfungsi untuk menaikan flokflok tersuspensi yang tidak dapat mengendap di dalam sel.

Teknik elektrokoagulasi memiliki beberapa kelebihan yaitu peralatan sederhana, mudah dalam pengoperasiaannya, waktu reaksi singkat, tidak memerlukan bahan kimia tambahan karena lebih banyak melibatkan proses fisika, selain itu teknik ini lebih ekonomis karena listrik yang digunakan relatif kecil. Dengan kelebihan dan pencapaian nilai efisiensi ini, maka dimungkinkan untuk aplikasi teknik ini pada skala yang lebih besar.

Prinsip Kerja Elektrokoagulasi

Prinsip dasar dari elektrokoagulasi adalah reaksi reduksi dan oksidasi (redoks). Dalam suatu sel elektrokoagulasi peristiwa oksidasi terjadi di anoda, sedangkan reduksi terjadi di katoda. Dalam reaksi elektrokoagulasi selain elektroda juga melibatkan air yang diolah yang berfungsi sebagai larutan elektrolit. Apabila dlam suatu elektrolit ditempatkan dua elektroda dan dialiri arus listrik searah maka akan terjadi peristiwa elektrokimia yaitu gejala dekomposisi elektrolit, dimana ion positif (kation) bergerak ke katoda dan menerima elektron yang direduksi dan ion negatif (anion) bergerak ke anoda dan menyerahkan elektron yang dioksidasi. Untuk proses elektrokoagulasi digunakan elektroda yang terbuat dari aluminium ( $\mathrm{Al}$ ) karena logam ini mempunyai sifat sebagai koagulan yang baik.

Proses elektrokoagulasi pada prinsipnya berdasarkan pada proses sel elektrolisis. Sel elektrolisis merupakan suatu alat yang dapat mengubah energi listrik DC (direct current) untuk menghasilkan reaksi elektrolik. Setiap sel elektrolisis mempunyai dua elektroda, katoda dan anoda. Anoda berfungsi sebagai koagulan dalam proses koagulasi-flokulasi yang terjadi di dalam sel tersebut. Sedangkan di katoda terjadi reaksi katodik dengan membentuk gelembung -gelembung gas hidrogen yang berfungsi untuk menaikkan flok-flok tersuspensi yang tidak dapat mengendap di dalam sel. Reaksi yang terjadi pada sel elektroda dengan anoda dan katoda yang digunakan aluminium adalah:

Reaksi pada Anoda : $\quad \mathrm{Al} \rightarrow \mathrm{Al}^{+3}+3 \mathrm{e}^{+3}$

Proses anodik mengakibatkan terlarutnya logam aluminium menjadi molekul ion $\mathrm{Al}^{+3}$. Ion yang terbentuk ini, di dalam larutan akan mengalami reaksi hidrolisis, menghasilkan padatan $\mathrm{Al}(\mathrm{OH})_{3} \cdot \mathrm{xH}_{2} \mathrm{O}$ yang tidak dapat larut lagi dalam air. Reaksinya :

$$
\mathrm{Al}+3 \mathrm{H}_{2} \mathrm{O} \rightarrow \mathrm{Al}(\mathrm{OH})_{3} \cdot x \mathrm{H} 2 \mathrm{O} \cdot \mathrm{Al}(\mathrm{OH})_{3} \cdot \mathrm{xH}_{2} \mathrm{O}
$$

yang terbentuk dalam larutan dapat berfungsi sebagai koagulan untuk proses koagulasi-flokulasi yang terjadi pada proses selanjutnya di dalam sel elektrokoagulasi. Setelah proses koagulasiflokulasi ini selesai maka kontaminan-kontaminan yang berada dalam air buangan dapat terpresipitasi dengan sendirinya.

\section{Reaksi pada Katoda : $2 \mathrm{H}_{2} \mathrm{O}+2 \mathrm{e} \rightarrow \mathrm{H}_{2}+2 \mathrm{OH}^{-}$}

Reaksi sel merupakan hasil reaksi dari proses anodik dan katodik yang terjadi secara serentak, laju mol eqivalen yang sama pada masing-masing elektroda. Hasil reaksi sel yang terjadi sangat bervariasi. Dapat berupa bahan-bahan yang terlarut dan ion-ion terlarut sepeti $\mathrm{Al}^{+3}$ dan $\mathrm{OH}$ atau berupa bahan padatan yang tidak dapat larut seperti $\mathrm{Al}_{2} \mathrm{O}_{3}, \quad \mathrm{Al}(\mathrm{OH})_{3}$, dan pembentukan $\mathrm{H}_{2}$. Berlangsungnya proses reaksi elektrodik mengakibatkan terjadinya perubahan komposisi 
elektrolit terutama kenaikan $\mathrm{pH}$ karena adanya pelepasan $\mathrm{OH}^{-}$dan gas $\mathrm{H}_{2}$ pada reaksi katodik. Besar atau kecilnya pengaruh-pengaruh tersebut tergantung pada rapat arus katoda dan jumlah $\mathrm{Al}^{+3}$ yang terhidrolisis. Adanya kenaikan $\mathrm{pH}$ karena reaksi katodik pada permukaan katoda akan mengakibatkan logam Aluminium terlapisi oleh suatu lapisan hidroksida yang mengendap (pasivitas).

Elektrokoagulasi mampu menyisihkan bernbagai jenis polutan dalam air, yaitu partikel tersuspensi, logam-logam berat, produk minyak bumi, warna pada zat pewarna, larutan humus, dan deflourinasi air. Selain itu, elektrokoagulasi dapat digunakan untuk pengolahan awal teknologi membran seperti reverse osmosis.

Pada elektrokoagulasi, arus kelistrikan mengalir diantara dua elektroda, coagulant diumpankan dari awal dengan electrolytic oksidasi bahan anoda. Dengan anoda besi, $\mathrm{Fe}(\mathrm{OH})_{\mathrm{n}}$ dengan $\mathrm{n}=2$ atau 3 dipasang di anoda. Penyederhanaan oksidasi, mekanisme penurunan dan skema anoda dan katoda elektroda besi dirumuskan sebagai berikut :

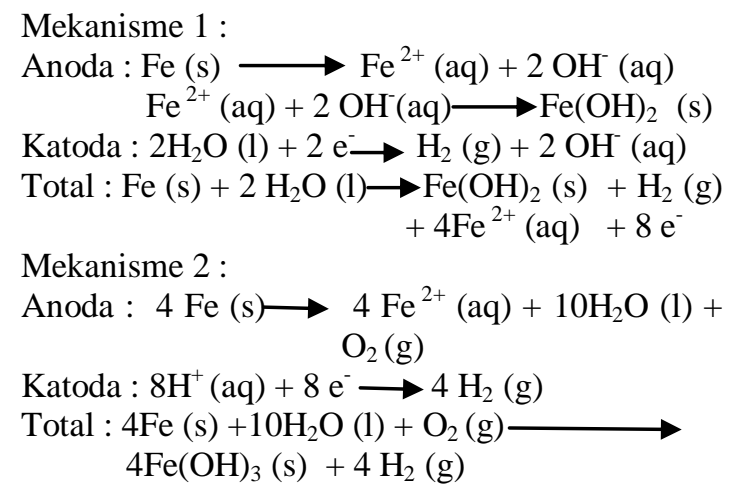

Sel elektrokoagulasi dioperasikan dengan menggunakan penyearah arus, power supply dengan rentang arus listrik 0-60 ampere dan tegangan listrik 0-15 volt, ampere meter digital dengan rentang arus listrik 0-20 ampere dan voltmeter digital dengan rentang tegangan listrik 0-300 volt DC. Pengaruh tegangan listrik terhadap penurunan COD dan beberapa parameter lain diobservasi dalam waktu reaksi selama 1 hingga 8 jam di dalam reaktor. Volume reaktor yang digunakan adalah 70 liter. Lembaran aluminium yang telah dipotong sesuai dengan ukuran, dihubungkan dengan power supply (PS). Setengahnya dengan kutub positip PS, bertindak sebagai katoda, dan setengahnya lagi dihubungkan dengan kutub negatip PS, selanjutnya berindak sebagai Anoda. Rangkaian yang digunakan merupakan rangkaian paralel. Berat aluminium telah ditimbang sebelum dan setelah proses. Pelat aluminium yang digunakan adalah pelat yang umum di pasaran dengan kandungan
Al sebesar 95-99\%. Tebal pelat yang digunakan sebesar $3 \mathrm{~mm}$. Sebagai larutan elektrolit yang digunakan adalah LCPKS. LCPKS diambil dari Keluaran RANUT yang diperoleh dari PKS Adolina P.T. Perkebunan Nusantara IV. Adapun gambar dari rangkaian 1 set peralatan elektrokoagulasi dapat dilihat pada gambar 1 berikut ini :

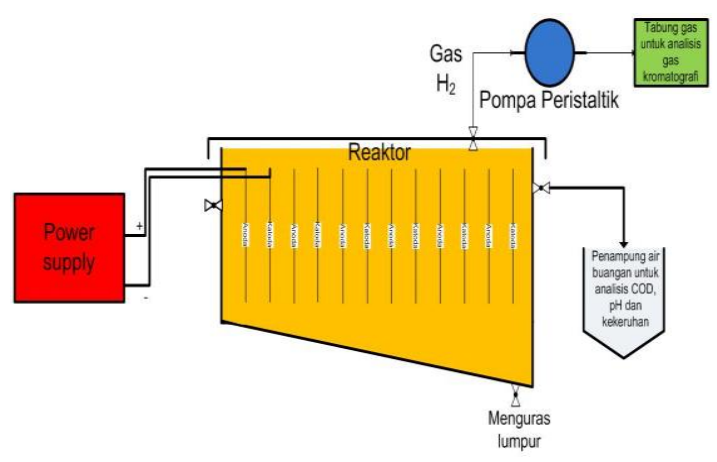

Gambar 1. Peralatan elektrokoagulasi

\section{Metodologi Penelitian}

Pengoperasian Sel

Sebelum pengoperasian proses elektrokoagulasi, semua bahan dan alat yang digunakan harus dalam keadaan baik, bagi menjamin tidak ada masalah pada proses yang akan dilakukan. Perhatian juga dilebihkan kepada elektroda dan kabel yang merupakan salah satu faktor penting dalam arus listrik, karena dapat menurunkan besar arus listrik apabila sambungan keduanya tidak dalam keadaan baik. Pengoperasian dimulai dengan memasukkan cairan pada reaktor. Setelah itu elektroda dipasang ke dalam reaktor dengan menyambungkan kabel kepada setiap elektroda.

Arus listrik yang digunakan berasal dari listrik AC yang dirubah menjadi arus DC menggunakan DC power supply dan rectifier sehingga memudahkan dalam mengatur tegangan yang akan melewati rangkaian sel. Dalam waktu tertentu dilakukan analisis sampel dalam waktu 8 jam dengan interval 1 jam. Seluruh analisis dilakukan sesuai dengan metode standar. Permukaan elektroda setelah reaksi akan mangalami pasivitas sehingga diperlukan pembersihan pada permukaan elektroda dengan menggunakan kertas pasir grade 400. Penelitian dilakukan dengan variasi tegangan 2 hingga 4 volt.

\section{Hasil dan Pembahasan}

\section{Analisa Awal Karakteristik Limbah Cair} Effluent RANUT

Limbah cair yang diolah dalam penelitian ini adalah limbah cair yang berasal dari buangan Reaktor Anaerobik Unggun Tetap (RANUT). Sesuai dengan tujuan utama penelitian ini yaitu untuk melihat persentase penyisihan polutan, 
maka perlu adanya analisa awal karakteristik limbah cair yang akan diolah. Analisa dilakukan pada setiap sampel limbah yang akan diolah, analisa yang dilakukan meliputi : COD, TS, TSS, $\mathrm{pH}$, dan turbiditas.

Adapun hasil analisa tersebut disajikan pada tabel 1 berikut ini:

Tabel 1. Karakteristik limbah awal

\begin{tabular}{|l|l|l|l|l|l|}
\hline No & $\begin{array}{l}\text { COD } \\
(\mathrm{mg} / \mathrm{l})\end{array}$ & $\begin{array}{l}\text { TS } \\
(\mathrm{mg} / \mathrm{l})\end{array}$ & $\begin{array}{l}\text { TSS } \\
(\mathrm{mg} / \mathrm{l})\end{array}$ & pH & $\begin{array}{l}\text { Turbiditas } \\
\text { NTU }\end{array}$ \\
\hline 1 & 1409,22 & 1250 & 918 & 7,8 & 942,33 \\
2 & 1484,5 & 1380 & 968 & 7,9 & 965,2 \\
3 & 1430,5 & 1250 & 924 & 7,7 & 1022,33 \\
4 & 1279,9 & 1051 & 871,6 & 7,6 & 899 \\
5 & 1250,25 & 1027 & 723 & 7,5 & 718 \\
6 & 1273,8 & 1039 & 745 & 7,5 & 726,9 \\
\hline
\end{tabular}

Dari hasil analisa di atas diketahui bahwa karakteristik effluent RANUT terutama untuk parameter TSS dan COD masih sangat jauh dari standar baku mutu limbah cair PKS yang berlaku. Secara fisik limbah ini berwarna coklat kehitaman, sedikit berbau dan temperatur kira-kira $35{ }^{\circ} \mathrm{C}$.

\section{Pengaruh Waktu Elektrokoagulasi Terhadap penyisihan COD}

Chemical Oxygen Demand (COD) adalah parameter yang menggambarkan nilai kandungan bahan organik dalam limbah cair baik yang biodegradable maupun nonbiodegradable, dalam bentuk terlarut maupun tersuspensi. Dalam limbah cair pabrik kelapa sawit, kandungan bahan organik terlarut lebih besar daripada yang tersuspensi [7].

Pada proses pengolahan limbah cair RANUT, molekul-molekul bahan organik akan mengalami destabilisasi oleh koagulan dan juga medan listrik dalam larutan selama proses berlangsung. Ikatan-ikatan fisika antar molekul organik akan terputus sehingga memungkinkan molekul-molekul tersebut untuk teradsorpsi oleh flok-flok koagulan dan kemudian mengendap setelah mencapai berat yang cukup. Adanya gasgas hidrogen dan oksigen yang dihasilkan selama proses menyebabkan sebagian dissolved organic dan material terlarut lainnya mengalami flotasi, termasuk flok hidroksida yang menangkap sebagian limbah organik yang tidak terdeposit pada batang katoda. Flok-flok yang mengapung baru akan mengendap apabila telah mencapai berat yang cukup [8].

Dari gambar 2 terlihat bahwa penurunan COD semakin besar dengan peningkatan tegangan yang diberikan. Penurunan COD tertinggi diperoleh pada tegangan 5 volt pada waktu operasi 180 menit dengan penyisihan COD sebesar 81,32 \%. Turunnya konsentrasi COD menandakan berkurangnya senyawa organik dalam limbah cair, karena pada dasarnya pengukuran COD bertujuan untuk melihat banyaknya oksigen yang diperlukan untuk mengoksidasi senyawa organik dalam air. Hal ini sesuai dengan teori double layer bahwa lingkaran terdalam akan diisi oleh koagulan bermuatan positif akan menyerap ion-ion negatif yang terletak pada lingkaran lebih luar. Muatan positif dan negatif bertemu maka terjadi gaya Van der Waals (tarik menarik) antar kedua ion tersebut sehingga terjadi ikatan yang sangat kuat dan terbentuklah koagulan yang selanjutnya akan membentuk flok yang dapat menurunkan senyawa organik dalam limbah [8].

Gambar 2. berikut ini menunjukkan bahwa profil persentasi penurunan nilai COD terhadap waktu pada limbah RANUT yang diolah dalam reaktor elektrokoagulasi.

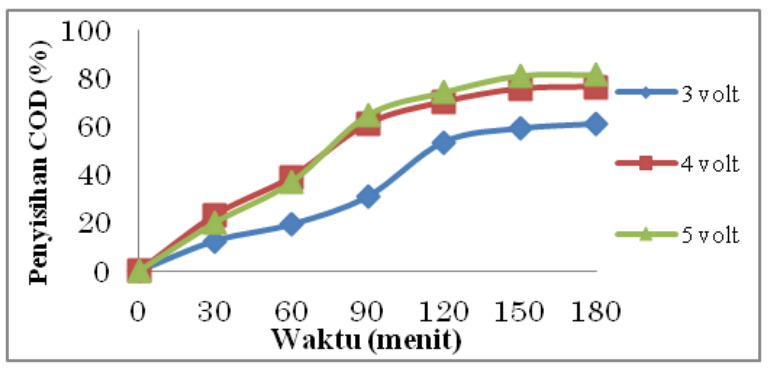

Gambar 2. Penyisihan COD Terhadap Waktu

\section{Pengaruh Waktu Terhadap Penurunan Turbiditas limbah Cair PKS}

Penyisihan kadar polutan dengan menggunakan teknik elektrokoagulasi pada dasarnya merupakan proses penyisihan secara fisika terhadap polutan terutama polutan berupa partikel-partikel padat dan padatan tersuspensi. Hasil analisa penyisihan turbiditas ditunjukkan pada gambar 3 di bawah ini :

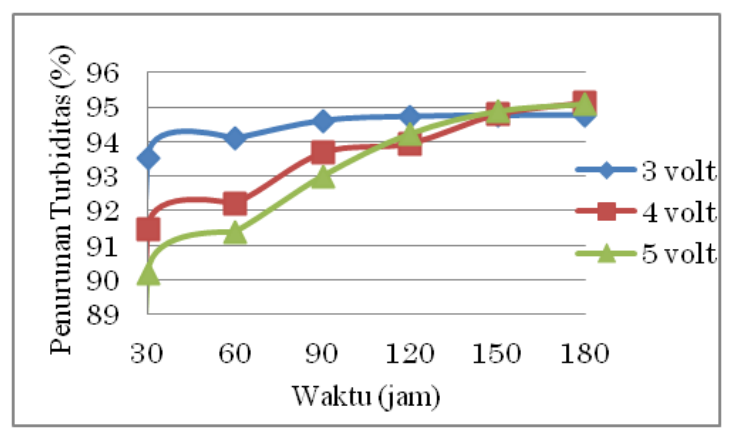

Gambar 3. Penyisihan Turbiditas terhadap Waktu

Dari gambar 3 terlihat bahwa persentase penyisihan turbiditas yang tertinggi diperoleh pada tegangan 5 volt dan pada waktu 180 menit dengan perolehan 95,08 \%. Nilai ini menunjukkan bahwa teknik elektrokoagulasi sangat efektif digunakan untuk menurunkan turbiditas. Nilai turbiditas dari limbah awal adalah 718 NTU menjadi 35,5 NTU pada hasil akhir olahan. Hasil 
ini sesuai dengan penelitian terdahulu bahwa elektrokoagulasi sangat efektif dalam menurunkan turbiditas dari limbah olahan [6].

\section{KESIMPULAN}

Dari hasil penelitian yang dilakukan mengenai pengolahan limbah cair PKS dari unit RANUT dengan teknik elektrokoagulasi dapat disimpulkan hal-hal berikut ini :

1. Persentasi penurunan tertinggi yang dihasilkan untuk COD adalah $81,32 \%$ dan turbiditas $95,08 \%$.

2. Nilai persentasi tertinggi diperoleh pada tegangan 5 volt dan waktu operasi 180 menit.

3. Semakin tinggi nilai tegangan yang diberikan maka akan semakin tinggi pula persentasi penyisihan yang diperoleh.

4. Limbah hasil olahan elektrokoagulasi sudah memenuhi baku mutu limbah cair PKS yaitu Keputusan Menteri Negara Lingkungan Hidup No. 51/Kep-MenLH/10/1995, tentang baku mutu limbah cair untuk industri minyak sawit.

\section{UCAPAN TERIMA KASIH}

kepada :

Penulis mengucapkan terima kasih

1. Lembaga Riset dan pengabdian masyarakat DIKTI

2. M. Ansori Nasution peneliti di PPKS, Medan

\section{DAFTAR PUSTAKA}

[1] Ardhani, A.F, Dwi Ismawati, Penanganan Limbah Cair Rumah Potong Hewan Dengan Metode Elektrokoagulasi, Skripsi, Jurusan Teknik Kimia, Universitas Diponegoro, Semarang, 2007.

[2] Bambang, Hari P, Mining Harsanti, Prosiding Seminar Nasional Teknik Kimia, Yogyakarta, 2010, D11-2.

[3] Ditjen PPHP, Pedoman Pengolahan Limbah Industri Kelapa Sawit, Subdit Pengelolaan Lingkungan Direktorat Pengolahan Hasil Pertanian. Jakarta, 2006.

[4] Husni, F., Pengolahan Limbah Cair Pabrik Kelapa Sawit Effluent RANUT (Reaktor Anaerobik Unggun Tetap) Menggunakan Teknik Elektrokoagulasi, Tesis, Jurusan Teknik Kimia, Fakultas Teknik, Universitas Sumatera Utara, Medan, 2010.

[5]Mukmin, A, Pengolahan Limbah Industri Berbasis Logam Dengan Teknologi Elektrokoagulasi Flotasi, Tesis, Jurusan Ilmu Lingkungan, Universitas Diponegoro, Semarang, 2006.

[6] Nasution M A, Yaakob Z, Ali E, Tasirin S M and Abdullah S R S, Electrocoagulation of Palm Oil Mill Effluent as Wastewater Treatment and Hidrogen Production Using
Electrode Aluminium, J. Environ, Qual.vol 49 (2011) 1332-9

[7]Wulfert K, dkk, Prosiding Pertemuan Teknis Kelapa Sawit, Pusat Penelitian Kelapa Sawit, 2000.

[8] Yulianto, Andik, dkk, Pengolahan Limbah Cair Industri Batik Pada Skala Laboratorium Dengan Menggunakan Metode Elektrokoagulasi, Skripsi, Jurusan Teknik Lingkungan, Universitas Islam Indonesia, Yogyakarta, 2009. 